\title{
Protein and fat absorption in prolonged diarrhoea in infancy
}

\author{
M D MANN, I D HILL, G M PEAT, AND M D BOWIE \\ Department of Paediatrics and Child Health, Red Cross War Memorial Children's Hospital, \\ and Institute of Child Health, University of Cape Town
}

SUMMARY ${ }^{15} \mathrm{~N}$-yeast protein absorption, nitrogen and fat retention, stool reducing substances, and lactate concentrations were measured in 22 infants who had had severe diarrhoea for 7 days. Stool losses of nitrogen and fat were large. and an appreciable proportion appeared to be endogenous. The supply of nitrogen and energy might have been a limiting factor in tissue repair if stool weight exceeded $30 \mathrm{~g} / \mathrm{kg}$ body weight a day. These results differ from those in older children with kwashiorkor complicated by diarrhoea of similar severity.

In most infants gastroenteritis or infectious diarrhoea is a self-limiting disease lasting 2 or 3 days. If severe diarrhoea persists there may be major problems in management and an appreciable mortality. Treatment is generally based on dietary manipulation and it has been stated that it is essential to maintain nutrition by continuing adequate food intake even if this actually prolongs the diarrhoea. ${ }^{1}$

This approach is based on studies on malnourished children. In kwashiorkor complicated by diarrhoea, the most common disturbance in gut function is disaccharide intolerance. There is almost invariably a striking response to dietary manipulation, particularly the introduction of lactose-free feeds. Even if lactose-induced diarrhoea is allowed to persist fat absorption and nitrogen retention are not affected although there is a moderate reduction in apparent nitrogen absorption. ${ }^{2}$ Children with kwashiorkor are generally older than 1 year whereas persistent or protracted diarrhoea most commonly complicates acute gastroenteritis in infants under age 6 months. There are also differences in cellular immunity ${ }^{3}$ and gut morphology. ${ }^{4}$

This paper reports the results of a study on protein absorption and nitrogen and fat balance in infants with prolonged diarrhoea.

\section{Patients and methods}

The infants aged between 3 weeks and 1 year had a history of diarrhoea for less than 72 hours when they were admitted to hospital for intravenous rehydration. Diarrhoea persisted and 6 days after admission they still required intravenous fluids to maintain hydration. No antibiotics or chemotherapeutic agents other than penicillin had been given and most infants had been fed on full-cream or modified cows' milk formula followed by a soybased formula. There was no oedema, and none of the skin lesions associated with nutritional diseases.

On day 7, 35 boys were taken into the study and nursed on metabolic beds for 5 days. Routine investigations included urine and stool specimens examined microscopically and cultured. Blood culture, haemoglobin, total serum protein, serum protein electrophoresis, serum electrolytes, $\mathrm{pH}, \mathrm{PCO}_{2}$, and standard bicarbonate estimations were also done. If clinically indicated the investigations were repeated. All the infants were given parenteral penicillin and gentamicin in case of undetected infection.

During the first 24 hours all the infants received $120 \mathrm{ml}$ of full-cream cows' milk formula per kg body weight. Infants were then allocated randomly to one of 3 commercial feeds; a full-cream cows' milk formula (Nespray), a soy-based formula with the carbohydrate as sucrose (Sobee), or a casein-based, low-lactose formula with glucose as the principal carbohydrate (AL 110). If the bacteriological screening tests showed that an infant had a urinary tract infection, a known pathogen in the stool, or a bacteraemia, he was excluded from the study. Three infants who were subsequently found to have monosaccharide intolerance were also excluded. The results of the 13 infants with demonstrable infection or monosaccharide intolerance will be reported in another paper. 
For the next 96 hours of study (days 8 to 11 after admission to hospital) the infants were fed $13-16 \mathrm{ml}$ per $\mathrm{kg}$ body weight of the allocated feed every 3 hours-that is 105 to $130 \mathrm{ml} / \mathrm{kg}$ a day. Fifteen $\mathrm{mg}$ per $\mathrm{kg}$ body weight of ${ }^{15} \mathrm{~N}$-yeast protein ${ }^{56}$ and a carmine marker were added to the third feed. All bottles were weighed before and after feeds. The bottle to which the ${ }^{15} \mathrm{~N}$-yeast protein had been added was rinsed thoroughly and the washing stored at $-20^{\circ} \mathrm{C}$ for subsequent analysis. Aliquots of the feeds were stored in the same way.

Each stool and urine specimen was collected separately and the time of evacuation noted. Urine was collected in bottles containing $1 \mathrm{ml}$ of toluene and $1 \mathrm{ml} 5 \mathrm{~mol} / 1$ hydrochloric acid. Stool specimens were frozen immediately. At the time of analysis the volume of each urine specimen, and weight of each stool were recorded. Aliquots of each urine specimen, stool, and feed, and of the washings of the ${ }^{15} \mathrm{~N}$-yeast protein feed were digested using the micro Kjeldahl technique. The total nitrogen content was measured by the phenol-hypochlorite method ${ }^{7}$ and the ${ }^{15} \mathrm{~N} /{ }^{14} \mathrm{~N}$ ratio with a Packard ${ }^{15} \mathrm{~N}$ analyser, after release of nitrogen with hypobromite. ${ }^{8}$

The total daily nitrogen intake and urine and stool excretion were calculated. These results were used to obtain values for nitrogen balance and apparent nitrogen absorption in a specified period. Apparent nitrogen absorption was defined as

$$
(\mathrm{N} \text { intake }-\mathrm{N} \text { in stool) } / \mathrm{N} \text { intake } \times 100 \%
$$

The absorption of ${ }^{15} \mathrm{~N}$-yeast protein was calculated from the ${ }^{15} \mathrm{~N}$ intake and the ${ }^{15} \mathrm{~N}$ content of the stool. ${ }^{6}$ Aliquots of stool of appropriate size were pooled for measurement of daily total stool reducing substances, ${ }^{9}$ lactate, ${ }^{10}$ and faecal fat excretion during the last 72 hours of the study period, days 9 to 11 after admission to hospital. ${ }^{11}$ Fat intake during this period was also measured. Total stool reducing substances were expressed as mmol glucose. Apparent fat absorption was calculated in the same way as apparent nitrogen absorption.

\section{Results}

Twenty-two infants had no demonstrable infection or monosaccharide intolerance. Seven received the full cream cows' milk formula, 7 the soy basedformula, and 8 the low-lactose formula. The medians and ranges of their ages, weights, weights as a percentage of their expected weight for age, and total serumprotein and albumin concentrations are given in Table 1.

In all groups there was a tendency for stool weight to decrease between days 8 and 11. The medians and ranges of stool weight, total stool reducing
Table 1 Median and range of age, weight, \% expected weight for age, total serum protein, and serum albumin concentrations

\begin{tabular}{|c|c|c|c|}
\hline & $\begin{array}{l}\text { Full-cream } \\
\text { milk } \\
(n=7)\end{array}$ & $\begin{array}{l}\text { Soy milk } \\
(n=7)\end{array}$ & $\begin{array}{l}\text { Low-lactose } \\
\text { milk } \\
(n=8)\end{array}$ \\
\hline Age (months) & $\begin{array}{l}3 \\
(0.8 \text { to } 11)\end{array}$ & $\begin{array}{l}5 \\
(0.8 \text { to } 9)\end{array}$ & $\begin{array}{l}4 \\
(2 \text { to } 8 \cdot 5)\end{array}$ \\
\hline Weight (kg) & $\begin{array}{l}4 \cdot 6 \\
(2 \cdot 2 \text { to } 7 \cdot 5)\end{array}$ & $\begin{array}{l}4 \cdot 0 \\
(2 \cdot 9 \text { to } 7 \cdot 5)\end{array}$ & $\begin{array}{l}4 \cdot 8 \\
(2 \cdot 5 \text { to } 8 \cdot 5)\end{array}$ \\
\hline$\%$ Expected weight for age & $\begin{array}{l}67 \\
(43 \text { to } 99)\end{array}$ & $\begin{array}{l}80 \\
(63 \text { to } 85)\end{array}$ & $\begin{array}{l}81 \\
(50 \text { to } 98)\end{array}$ \\
\hline Total serum protein $(\mathrm{g} / \mathrm{l})$ & $\begin{array}{l}50 \cdot 6 \\
(45 \cdot 0 \text { to } 64 \cdot 0)\end{array}$ & $\begin{array}{l}55 \cdot 6 \\
(48 \cdot 0 \text { to } 70 \cdot 7)\end{array}$ & $\begin{array}{l}54.0 \\
(44.0 \text { to } 76 \cdot 2)\end{array}$ \\
\hline Albumin (g/l) & $\begin{array}{l}26.9 \\
(22.8 \text { to } 31.4)\end{array}$ & $\begin{array}{l}29 \cdot 0 \\
(22 \cdot 5 \text { to } 33 \cdot 9)\end{array}$ & $\begin{array}{l}25 \cdot 6 \\
(22 \cdot 8 \text { to } 36 \cdot 1)\end{array}$ \\
\hline
\end{tabular}

substances, stool lactate, and apparent nitrogen absorption on day 8 are given in Table 2 with the values for the absorption of ${ }^{15} \mathrm{~N}$-yeast protein. The relationship between stool weight and ${ }^{15} \mathrm{~N}$-yeast protein absorption is shown in Fig. 1.

All the infants had a distinct, sharp, symmetrical peak of ${ }^{15} \mathrm{~N}$ in the stool $1 \frac{1}{2}$ to 18 hours after the ingestion of ${ }^{15} \mathrm{~N}$. This coincided with the passage of the carmine marker. After this peak, stool ${ }^{15} \mathrm{~N}$ excretion appeared to be related to the severity of the diarrhoea. When stool weight was less than 30 $\mathrm{g} / \mathrm{kg}$ body weight, stool ${ }^{15} \mathrm{~N}$ was low and followed the same course as urinary ${ }^{15} \mathrm{~N}$. The ${ }^{15} \mathrm{~N}$ atoms $\%$ excess in stool was between one-tenth and one-half that in urine passed at the same time. As stool weight increased, and particularly when it was over $80 \mathrm{~g} / \mathrm{kg}$ a day, the same general pattern occurred, but several small late peaks appeared to be superimposed on the overall trend. There was always a distinct gap between the initial peak and these late peaks. Like the initial peaks, the late peaks were sharp and symmetrical with no evidence of tailing. Between the late peaks, ${ }^{15} \mathrm{~N}$ atoms $\%$ excess in the stool was one-tenth to one-half that in urine passed at the same time, but the peak values were similar to those

Table 2 Medians and ranges of stool weight, total stoolreducing substances, stool lactate, and apparent nitrogen absorption on day 8 , and of ${ }^{15} N$-yeast protein absorption

\begin{tabular}{|c|c|c|c|}
\hline & $\begin{array}{l}\text { Full-cream } \\
\text { milk }\end{array}$ & Soy milk & $\begin{array}{l}\text { Low-lactose } \\
\text { milk }\end{array}$ \\
\hline $\begin{array}{l}\text { Stool weight (g/ } \mathrm{kg} \mathrm{a} \\
\text { day) }\end{array}$ & $\begin{array}{l}122 \\
(7 \cdot 3 \text { to } 180)\end{array}$ & $\begin{array}{l}62 \\
\text { (14 to } 167)\end{array}$ & $\begin{array}{l}59 \\
(10 \text { to } 154)\end{array}$ \\
\hline $\begin{array}{l}\text { Total stool reducing } \\
\text { substances (mmol } \\
\text { glucose } / \mathrm{kg} \text { a day) }\end{array}$ & $\begin{array}{l}0.09 \\
(0 \text { to } 1 \cdot 42)\end{array}$ & $\begin{array}{l}0.04 \\
(0.03 \text { to } 0.65)\end{array}$ & $\begin{array}{l}0.18 \\
(0.02 \text { to } 0.79)\end{array}$ \\
\hline $\begin{array}{l}\text { Stool lactate (mmol/ } / \mathrm{kg} \\
\text { a day) }\end{array}$ & $\begin{array}{l}1 \cdot 2 \\
(0.07 \text { to } 16 \cdot 6)\end{array}$ & $\begin{array}{l}1 \cdot 4 \\
(0.09 \text { to } 13 \cdot 2)\end{array}$ & $\begin{array}{l}2 \cdot 6 \\
(0 \cdot 03 \text { to } 15 \cdot 1)\end{array}$ \\
\hline $\begin{array}{l}\text { Apparent nitrogen } \\
\text { absorption (\%) }\end{array}$ & $\begin{array}{l}44 \\
(-32 \text { to } 91)\end{array}$ & $\begin{array}{l}47 \\
(-136 \text { to } 83)\end{array}$ & $\begin{array}{l}53 \\
(-12 \text { to } 86)\end{array}$ \\
\hline $\begin{array}{l}15 N \text {-yeast protein } \\
\text { absorption (\%) }\end{array}$ & $\begin{array}{l}79 \\
\text { (57 to } 96)\end{array}$ & $\begin{array}{l}89 \\
(69 \text { to } 98)\end{array}$ & $\begin{array}{l}64 \\
(16 \text { to } 88)\end{array}$ \\
\hline
\end{tabular}




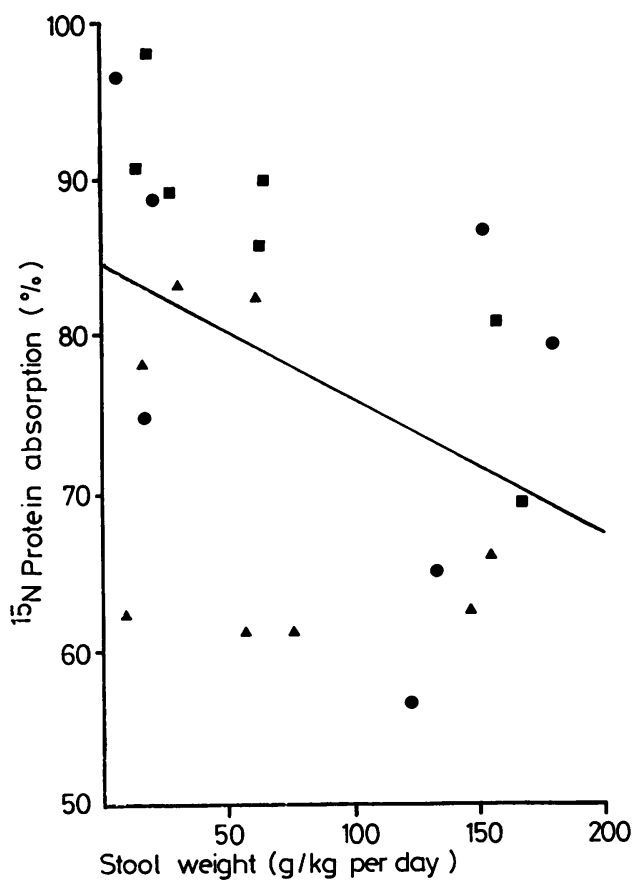

Fig. 1 Relationship between ${ }^{15} \mathrm{~N}$-yeast protein absorption and stool weight in infants fed on full-cream cows' milk (O), soy milk $(\square)$, and low-lactose milk $(\Delta)$.

of the urinary values. They did not exceed the initial peak urine values. These late stool peaks did not occur at regular intervals. In all the infants there was an overall trend for the peaks to become smaller but there were often'large differences in the amplitude of successive peaks. The time between the late peaks was not constant and there was no relationship between the weight of the stool specimen and the ${ }^{15} \mathrm{~N}$ content.

Table 3 Medians and ranges of stool weight, total stool reducing substances, stool lactate, nitrogen intake, apparent nitrogen absorption, and nitrogen balance on days 9 to 11 inclusive

\begin{tabular}{|c|c|c|c|}
\hline & $\begin{array}{l}\text { Full-cream } \\
\text { milk }\end{array}$ & Soy milk & $\begin{array}{l}\text { Low lactose } \\
\text { milk }\end{array}$ \\
\hline Stool weight (g/kg a day) & $\begin{array}{l}92 \\
(13 \text { to } 205)\end{array}$ & $\begin{array}{l}30 \\
(9 \text { to } 139)\end{array}$ & $\begin{array}{l}24 \\
(14 \text { to } 229)\end{array}$ \\
\hline $\begin{array}{l}\text { Total stool reducing } \\
\text { substances (mmol } \\
\text { glucose/kg a day) }\end{array}$ & $\begin{array}{l}0 \cdot 13 \\
(0 \text { to } 2 \cdot 7)\end{array}$ & $\begin{array}{l}0.07 \\
(0.0 \text { to } 1.6)\end{array}$ & $\begin{array}{l}0.73 \\
(0.02 \text { to } 3 \cdot 25)\end{array}$ \\
\hline $\begin{array}{l}\text { Stool lactate ( } \mathrm{mmol} / \mathrm{kg} \\
\text { a day) }\end{array}$ & $\begin{array}{l}7 \cdot 5 \\
(1 \cdot 3 \text { to } 204 \cdot 1)\end{array}$ & $\begin{array}{l}5 \cdot 8 \\
(0.6 \text { to } 43 \cdot 7)\end{array}$ & $\begin{array}{l}9 \cdot 3 \\
(1 \cdot 3 \text { to } 171 \cdot 3)\end{array}$ \\
\hline $\begin{array}{l}\text { Nitrogen intake } \\
\text { (mmol/kg a day) }\end{array}$ & $\begin{array}{l}64 \\
(46 \text { to } 84)\end{array}$ & $\begin{array}{l}77 \\
(55 \text { to } 100)\end{array}$ & $\begin{array}{l}77 \\
\text { (68 to } 90)\end{array}$ \\
\hline $\begin{array}{l}\text { Apparent nitrogen } \\
\text { absorption (\%) }\end{array}$ & $\begin{array}{l}34 \\
(-71 \text { to } 84)\end{array}$ & $\begin{array}{l}50 \\
(7 \text { to } 92)\end{array}$ & $\begin{array}{l}69 \\
(-139 \text { to } 84)\end{array}$ \\
\hline $\begin{array}{l}\text { Nitrogen retention } \\
(\mathrm{mmol} / \mathbf{k g} \text { a day) }\end{array}$ & $\begin{array}{l}-1 \cdot 6 \\
(-70 \text { to } 30)\end{array}$ & $\begin{array}{l}6 \cdot 8 \\
(-19 \text { to } 28)\end{array}$ & $\begin{array}{l}23 \\
(121-\text { to } 47)\end{array}$ \\
\hline
\end{tabular}

Table 4 Medians and ranges of fat intake, apparent fat absorption, and fat balance on days 9 to 11 inclusive

\begin{tabular}{|c|c|c|c|}
\hline & $\begin{array}{l}\text { Full cream } \\
\text { milk }\end{array}$ & Soy milk & $\begin{array}{l}\text { Low lactose } \\
\text { milk }\end{array}$ \\
\hline Fat intake ( $\mathrm{g} / \mathrm{kg}$ a day) & $\begin{array}{l}2 \cdot 8 \\
(2 \cdot 3 \text { to } 3 \cdot 3)\end{array}$ & $\begin{array}{l}2.7 \\
(2.3 \text { to } 3.0)\end{array}$ & $\begin{array}{l}3 \cdot 1 \\
(2 \cdot 5 \text { to } 3 \cdot 5)\end{array}$ \\
\hline $\begin{array}{l}\text { Apparent fat absorption } \\
(\%) \\
\text { Fat retention (g/kg a day) }\end{array}$ & $\begin{array}{l}34 \\
(32 \text { to } 74) \\
0.99 \\
(-0.99 \text { to } \\
2 \cdot 17)\end{array}$ & $\begin{array}{l}36 \\
(-25 \text { to } 86) \\
0.98 \\
(-0.64 \text { to } \\
2.33)\end{array}$ & $\begin{array}{l}50 \\
(16 \text { to } 91) \\
1 \cdot 29 \\
(0 \cdot 49 \text { to } 2 \cdot 51)\end{array}$ \\
\hline
\end{tabular}

Tables 3 and 4 give the medians and ranges of stool weight, total stool reducing substances, stool lactate, nitrogen intake, apparent nitrogen absorption, nitrogen balance, fat intake, apparent fat absorption, and fat balance on days 9 to 11 inclusive. Figs 2 to 6 show the relationship between stool weight and nitrogen balance, apparent nitrogen absorption, apparent fat absorption, total stool reducing substances, and stool lactate.

\section{Discussion}

It has been assumed that the initial stool ${ }^{15} \mathrm{~N}$ peak associated with the passage of the carmine marker was unabsorbed ${ }^{15} \mathrm{~N}$-yeast protein and that the rest of the ${ }^{15} \mathrm{~N}$ was absorbed. ${ }^{6}$ This is probable in those infants who did not have multiple small late peaks

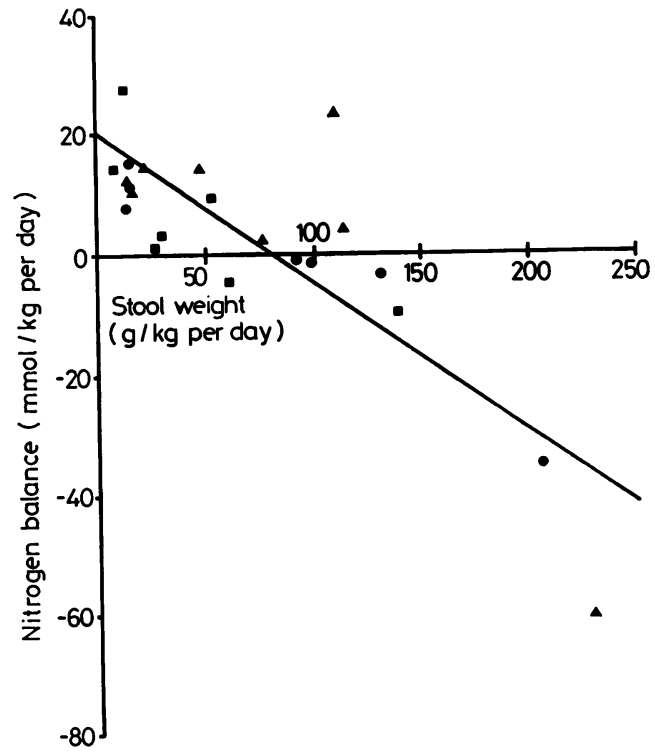

Fig. 2 Relationship between nitrogen retention and stool weight on days 9 to 11 inclusive in infants fed on full-cream cows' milk (O), soy milk $(\mathbb{\square})$, and lowlactose milk $(\mathbf{\Delta})$. 


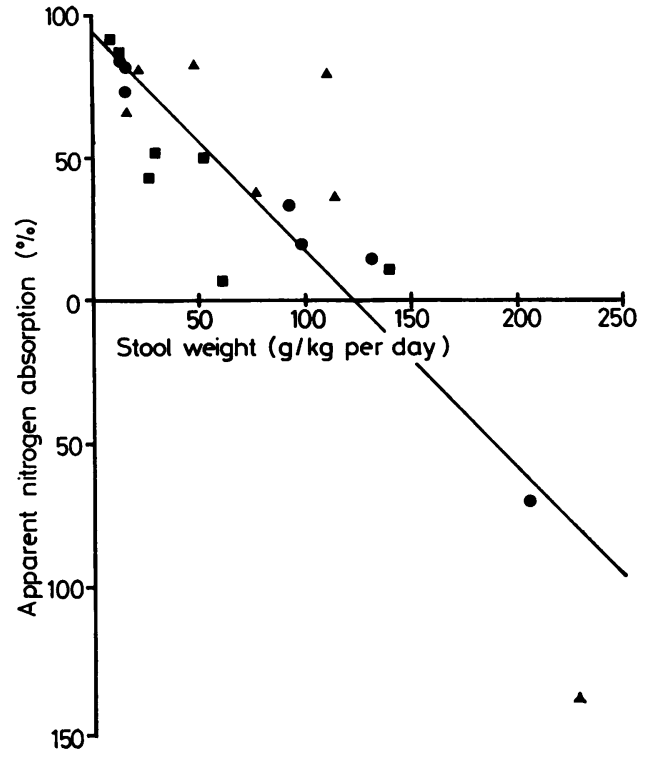

Fig. 3 Relationship between apparent nitrogen absorption and stool weight on days 9 to 11 inclusive in infants fed on full-cream cows' milk (O), soy milk (ם), and low-lactose milk (A).

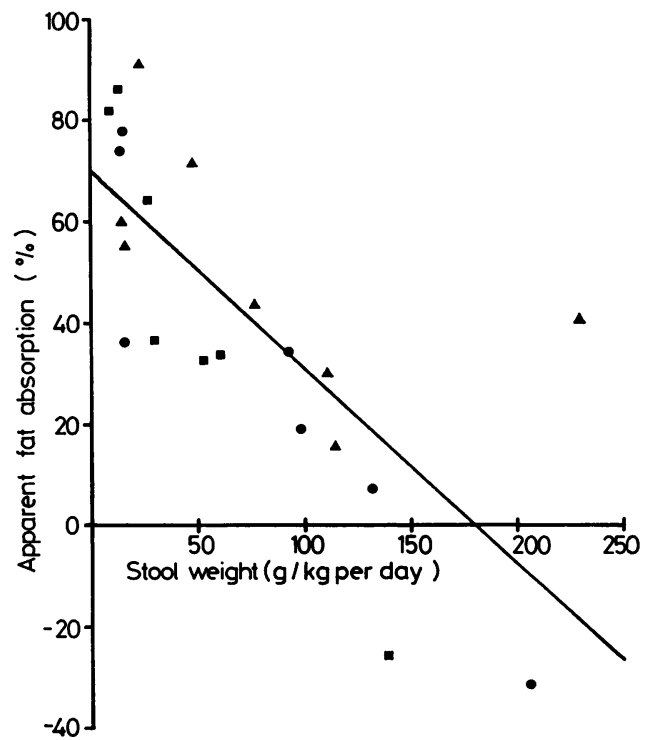

Fig. 4 Relationship between apparent fat absorption and stool weight on days 9 to 11 inclusive in infants fed on full-cream cows' milk (O), soy milk $(\square)$, and low-lactose milk (A).

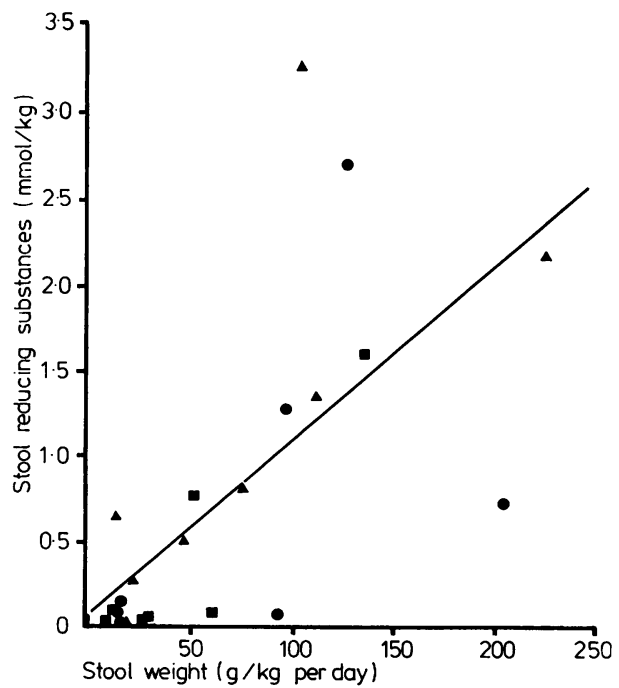

Fig. 5 Relationship between total stool reducing substances and stool weight on days 9 to 11 inclusive in infants fed on full-cream cows' milk (O), soy milk ( $\square)$, and low-lactose milk ( $\mathbf{\Delta})$.

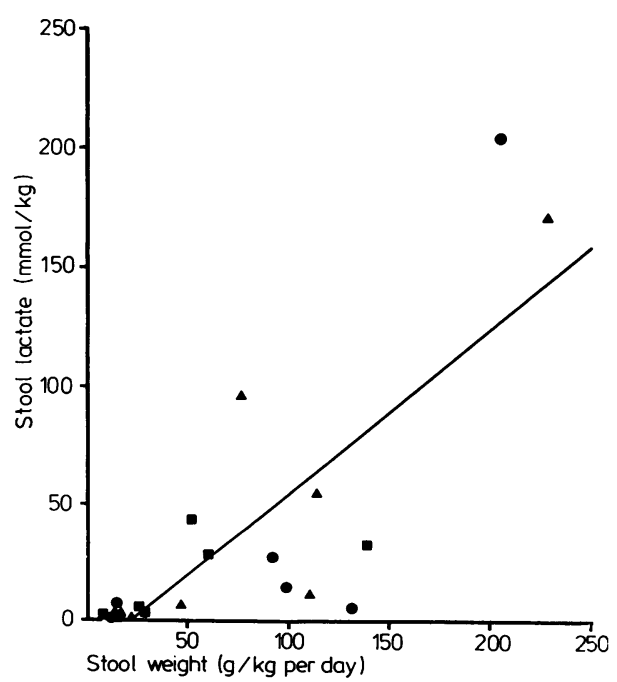

Fig. 6 Relationship between stool lactate and stool weight on days 9 to 11 inclusive in infants fed on full-cream cows' milk (O), soy milk (ם), and low-lactose milk $(\mathbf{\Delta})$. 
of ${ }^{15} \mathrm{~N}$ in the stool. It is possible that the late peaks were unabsorbed ${ }^{15} \mathrm{~N}$-yeast protein as there is a wide divergence between different markers of intestinal transit time in children with gastroenteritis. Even if this were so the additional amount of ${ }^{15} \mathrm{~N}$ unabsorbed would be less than $10 \% \cdot{ }^{15} \mathrm{~N}$-yeast protein absorption is only moderately reduced and does not fall rapidly with increasing stool weight.

Apparent nitrogen absorption was very poor, falling rapidly with increasing stool weight. If the absorption of milk and soy protein is similar to that of yeast protein most of the nitrogen in the stool would have been endogenous in origin. A significant proportion of this nitrogen must have been derived from pools which are not labelled with significant amounts of ${ }^{15} \mathrm{~N}$. Likely sources are gastrointestinal mucosa, secretions, and plasma proteins. Most infants presenting at this hospital with acute diarrhoea have serum albumin levels above $30 \mathrm{~g} / \mathrm{l}^{12}$ The low levels found in these infants on the 7th day of persistent diarrhoea could be interpreted as evidence for significant gastrointestinal loss of plasma protein. Another possible source is the amino-acid pool. Although this is labelled with significant amounts of ${ }^{15} \mathrm{~N}$ the level of enrichment falls rapidly. ${ }^{5}$ Ghadimi et al. ${ }^{13}$ found markedly increased levels of amino-acid in the stool in diarrhoeal disease as well as increased loss of protein and total nitrogen. Whatever the source of the endogenous faecal nitrogen, the losses in stool were so great that it is unlikely that the infants had sufficient nitrogen available for tissue repair let alone normal growth. This is supported by the finding of a low or even negative nitrogen balance (retention).

An energy deficit is also likely as the large nitrogen losses were associated with high stool fat levels. The apparent absorption of both nitrogen and fat fell as stool weight increased with very low or negative values when this was more than $80 \mathrm{~g} / \mathrm{kg}$ a day. The finding of negative fat balances in a few children was particularly surprising and suggests that like nitrogen, much of the fat in the stool was endogenous in origin. The most likely sources are massive exfoliation of mucosa and the loss of free fatty acids into the lumen of the gut. ${ }^{14}$

Gut function in these infants appears to differ from that found in older children with kwashiorkor. In this study the impairment of apparent absorption of nitrogen and fat was much greater than that in kwashiorkor complicated by diarrhoea of similar severity. Disaccharide intolerance appears to be less important. Although stool lactate and reducing substances rose as stool weight increased, there was a poor response to dietary manipulation. In contrast disaccharide intolerance, particularly lactose intoler- ance, is a major factor in determining the severity of the diarrhoea of kwashiorkor. ${ }^{15}$ Infants with prolonged diarrhoea therefore differ from older children with kwashiorkor complicated by diarrhoea in the magnitude of stool nitrogen and fat losses and possibly in the principal mechanism of the diarrhoea.

The continuing wastage of essential nutrients in the presence of impaired absorption makes it unlikely that an adequate oral food intake can be achieved in the infant with severe diarrhoea. A solution to this problem would be the early introduction of total intravenous nutrition but this is not practical if large numbers of infants with persistent diarrhoea require treatment. Another possibility is treatment which will terminate or reduce the severity of the diarrhoea as the stool losses increase with stool volume. In our hands the use of an antibacterial/cholestyramine cocktail has proved very effective. ${ }^{16}$

We thank Professor O A M Lewis of the Department of Botany, University of Cape Town, for allowing us to use the ${ }^{15} \mathrm{~N}$ analyser, and the South African Medical Research Council, the Mobil Research Associateship, and the McCaul Bell bequest for financial and technical support.

\section{References}

1 Pierce N F. Intestinal immunization with soluble bacterial antigens: the example of cholera toxoid. In: Elliott $\mathrm{K}$, $\mathrm{Knight} \mathrm{J}$, eds. Acute diarrhoea in childhood. Ciba Foundation Symposium 42, New Series. New York, Elsevier/ North-Holland, 1976: 22.

2 Bowie M D. Effect of lactose-induced diarrhoea on absorption of nitrogen and fat. Arch Dis Child 1975; 50: $363-6$.

3 Morison A, Beatty D W, Bowie M D. Cellular immune function in marasmic and underweight children with prolonged diarrhoea. $S$ Afr Med J 1978; 54: 7-9.

4 Kaschula R O C, Gajjar P D, Mann M D, et al. Infantile jejunal mucosa in infection and malnutrition. Isr J Med Sci 1979; 15: 356-61.

5 Crane $\mathrm{C} \mathrm{W}$, Neuberger $\mathrm{A}$. The digestion and absorption of protein by normal man. Biochem $J$ 1960; 74: 313-23.

${ }^{6}$ Read W W C, McLaren D S, Tchalian M. ${ }^{15} \mathrm{~N}$ studies of endogenous faecal nitrogen in infants. Gut $1974 ; 15$ : 2-33.

7 Munro H N, Fleck A. Analysis of tissue and body fluids for nitrogeneous constituents. In Munro $\mathrm{H} \mathrm{N}$, ed. Mammalian protein metabolism. Vol. III. New York: Academic Press, 1969: 423-525.

8 Sprinson D B, Rittenberg D. The rate of utilization of ammonia for protein synthesis. J Biol Chem 1949; 180: 704-14.

9 Henry R J. Clinical chemistry. New York: Harper \& Row, 1966: 620-48.

10 Gutman I, Wahlefeld A G. L-(+)-Lactate. Determination with lactate dehydrogenase and NAD. In: Bergmeyer H V, ed. Methods of enzymatic analysis. Vol. 3. New York: Verlag Chemie and Academic Press, 1974: 1464-72.

11 van der Kamer J H, Huinink H, Ten B, Weyers H A. 
Rapid method for the determination of fat in faeces. J Biol Chem 1949; 177: 347-55.

12 Beatty D W, Mann M D, Heese $\mathbf{H ~ d e V}$, Berger G M. Acute dehydrating gastroenteritis in undernourished infants. The diagnosis and correction of electrolyte and metabolic abnormalities. S Afr Med J 1974; 49: 613-5.

13 Ghadimi H, Kumar S, Abaci F. Endogenous amino acid loss and its significance in infantile diarrhoea. Pediatr Res 1973; 7: 161-8.

14 Waldram R. Mechanisms of lipid loss from the small intestinal mucosa. Gut 1975; 16: 118-24.
15 Bowie M D. MD thesis, University of Cape Town, 1971.

16 Bowie M D, Mann M D, Hill I D. The bowel cocktail. Pediatrics 1981; 67: 920-1.

Correspondence to Dr M D Mann, Institute of Child Health, Red Cross War Memorial Children's Hospital, 7700 Rondebosch, Cape, South Africa.

Received 7 July 1981

\title{
British Paediatric Association
}

\author{
Annual meetings \\ 1982 20-24 April Aviemore Centre, Scotland \\ 1983 12-16 April York University \\ 1984 10-14 April York University \\ 1985 16-20 April York University \\ 1986 15-19 April York University
}

